\title{
Distribution of Xylomoia graminea (Graeser, 1889) (Lepidoptera: Noctuidae) in Poland
}

\author{
Jarosław BURY* and Witold ZAJDA** \\ *Markowa 1498,37-120 Markowa,Poland; e-mail: jarekbury2@wp.pl, \\ **Instytut Systematyki i Ewolucji Zwierzat PAN, ul Stawkowska 17, 31-016 Kraków, Poland; \\ e-mail: zajda@isez.pan.krakow.pl
}

\begin{abstract}
A review of distribution and new data on the occurrence of the noctuid moth Xylomoia graminea (Graeser, 1889 ) in Poland are given. The new material includes observations collected from 2005 to 2010 in Malopolska, Podkarpacie and Podlasie regions. Xylomoia graminea (Graeser, 1889) is observed for the first time in Pogórze Dynowskie, Kotlina Jasielsko-Krośnieńskia, Pogórze Wiśnickie and Garb Tenczyński in south-eastern and southern Poland.
\end{abstract}

Key words: Lepidoptera, Noctuidae, Noctuinae, Xylomoia graminea, Poland, expansion, faunistics

\section{INTRODUCTION}

Xylomoia graminea (Graeser, 1889) is a lepidopteran species of the family Noctuidae, Latreille, 1809, subfamily Noctuinae, Latreille, 1809 and genus Xylomoia Staudinger, 1892.

The genus Xylomoia Staudinger, 1892 is represented world-wide by 8 lepidopteran species, six of which have been reported from the Palaearctic (Xylomoia fusei Sugi, 1976, found in Japan; Xylomoia apameoides Hacker, 1989, found in Turkey; two species known from Europe and Asia: Xylomoia retinax Mikkola, 1998 and Xylomoia graminea (Graeser, 1889), and two species occurring only in Europe: Xylomoia stangelmaieri Mikkola, 1998 and Xylomoia strix Mikkola, 1980), and the other two have been found in the Nearctic (Xylomoia indirecta (Grote, 1875) and Xylomoia chagnoni Barnes et Benjamin, 1917) (Mikkola 1998, Lafontaine \& Schmidt 2010, Karsholt \& Nieukerken 2011).

$X$. graminea is a species with a Euro-Siberian distribution whose current range includes a large part of the Palaearctic, extending from Japan, Korea, northern China and the Russian Far East to eastern regions of Poland (Fig. 1.) (Graeser 1889, Herz 1904, Sugi 1982, Sviridov 1985, Mikkola 1998). For almost 100 years, this species was only known from eastern Asia. It was first reported in Europe from the southern European part of Russia, near Rostov-on-Don, in 1981 (Poltavsky \& Artohin 2000), and subsequently from Poland in 1988 (Nowacki 1989). It has also been recorded in Ukraine (Klyuchko 1995, Klyuchko et al., 2001) and Lithuania (Švitra et al., 2011). It has not been reported from any other country in Europe to date (Zilli et al. 2005, Karsholt \& Nieukerken 2011).

In Poland, the species had previously only been found in north-eastern and eastern regions. Its southernmost localities were two sites within one $10 \times 10 \mathrm{~km}$ UTM square in Roztocze Poludniowe. The eastern regions of Poland were considered the western boundary of its global range (Fig. 1.) (Nowacki 1989, 1992, 1993, Kokot 1995, Lupiński 1996, Nowacki \& Hołowiński 1999, Buszko \& Nowacki 2000, Wąsala 2001, Łupiński \& Wasiluk 2002, Nowacki \& Wasiluk 2004, European Biodiversity Survey 2008, Nowacki \& Frąckiel 2010). 


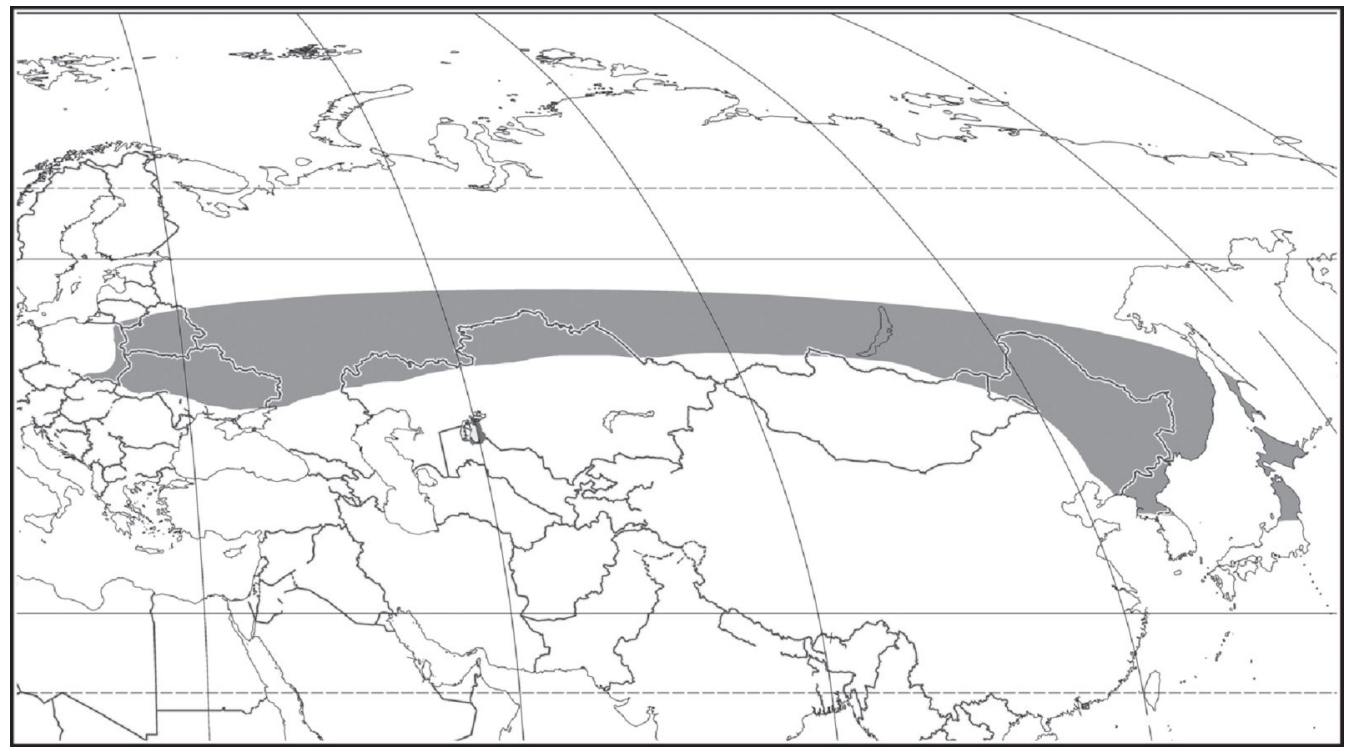

Fig. 1. Distribution range of Xylomoia graminea based on the literature and own observations. No data from Belarus, Kazakhstan and Mongolia.

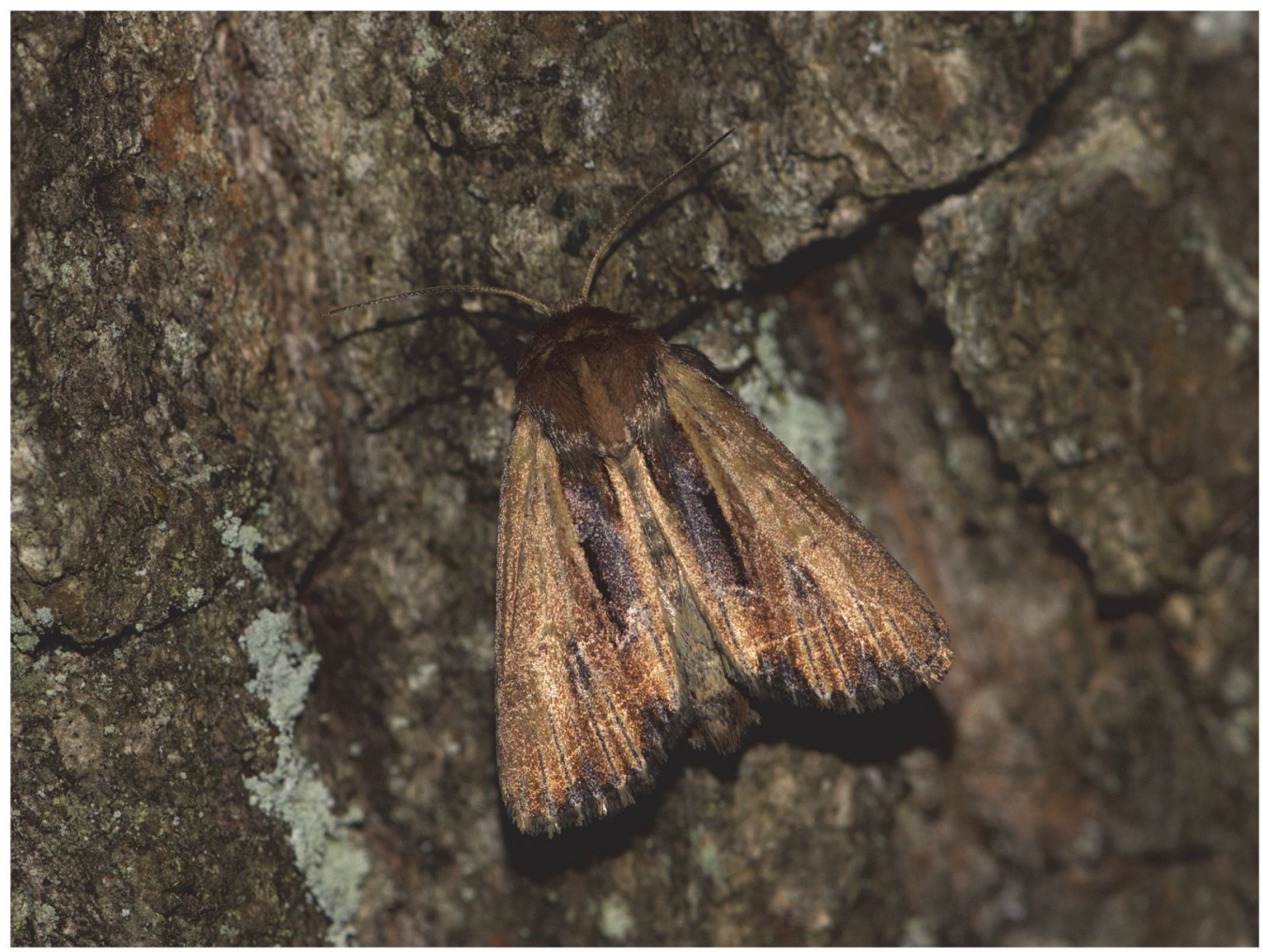

Fig. 2. Xylomoia graminea - Poland, Pogórze Dynowskie, Tarnawka, 09 VI 2010, Photo by J. Bury. 
$X$. graminea are small moths of a stout body build that is typical of most representatives of the family Noctuidae. The wing span is $28-31 \mathrm{~mm}$. The basic colouration of the fore wings is brown with a yellowish tinge. The central field is bordered by whitish, slightly dentate stripes. There is a narrow elongated black band in the inferior part of the central field. The hind wing is light in colour, grey-brown with a rather indistinct dark stripe (Fig. 2). The structure of the copulatory apparatus of the male and female is described in Nowacki (1989).

Just like its cognate species (Buszko 2004, 2010), X. graminea is associated with primeval moist habitats, predominantly lush sedge meadows, transitory bogs and rush communities. In the western part of the range, the moths occur from the end of May until early July, while in the east they can be observed even in mid-August (Nowacki \& Holowiński 1999, Mikkola 1980, 1998, Sviridov 1985).

The biology of the species is not well known. Caterpillar is described by Ahola \& Silvonen (2008). There is no known host plants for the caterpillars and there is no description of overwintering stage in nature. In laboratory conditions, caterpillars have been reared on Phragmites sp. in an ex ovo rearing (Ahola \& Silvonen 2008).

This paper aims to present the current knowledge on the distribution of X. graminea in Poland.

\section{METHODS}

All specimens were captured by being attracted to $250-500 \mathrm{~W}$ mercury vapour lamps. The moths were preserved in a manner typical for Macrolepidoptera. Evidence specimens are stored in the authors' private collections. Some specimens were followed without harvesting them and photographs were taken.

Mesoregion names are given according to (Kondracki 2002). UTM (Universal Transverse Mercator) co-ordinates (10x10 km grid) are also given for each locality.

Table 1.. Chronological review of the literature data on the occurrence of Xylomoia graminea in Poland

\begin{tabular}{|c|c|c|c|c|}
\hline $\begin{array}{c}\text { First } \\
\text { reported }\end{array}$ & Name of locality & Mesoregion & UTM & Reference \\
\hline \multirow[t]{2}{*}{1988} & Siedliska & Roztocze Wschodnie & FA87 & Nowacki 1989, Nowacki 1992 \\
\hline & Obrocz & Roztocze Środkowe & FB40 & Nowacki 1989, Nowacki 1992 \\
\hline \multirow[t]{2}{*}{$1988-1990$} & Hrebenne & Roztocze Wschodnie & FA87 & Nowacki 1992 \\
\hline & Kąty Drugie & Roztocze Środkowe & FB41 & Nowacki 1992 \\
\hline 1992 & Rygol & Równina Augustowska & FE57 & Kokot 1995 \\
\hline 1993 & Kosyń & $\begin{array}{l}\text { Równina Łęczyńsko- } \\
\text { Włodawska }\end{array}$ & FB79 & $\begin{array}{l}\text { Nowacki } 1993 \text {, Nowacki \& } \\
\text { Hołowiński } 1999\end{array}$ \\
\hline 1996 & Losice & Wysoczyzna Siedlecka & FC18 & Lupiński 1996 \\
\hline $1993-1998$ & $\begin{array}{l}\text { Podlaski, } \\
\text { Macoszyn, Stulno }\end{array}$ & $\begin{array}{l}\text { Równina Łęczyńsko- } \\
\text { Włodawska }\end{array}$ & $\begin{array}{l}\text { FC70, } \\
\text { FB79, } \\
\text { FB89 }\end{array}$ & Nowacki \& Hołowiński 1999 \\
\hline $1996-2000$ & Serpelice & Podlaski Przełom Bugu & FC49 & Lupiński \& Wasiluk 2002 \\
\hline 1996 & Woźniki & Wysoczyzna Siedlecka & $\mathrm{FC} 28$ & Nowacki \& Wasiluk 2004 \\
\hline 1999 & Zaborze & Wysoczyzna Siedlecka & FC19 & Nowacki \& Wasiluk 2004 \\
\hline 2000 & Pogorzelce & Równina Bielska & FD94 & Wąsala 2001 \\
\hline 2002 & Mielnik & $\begin{array}{l}\text { Podlaski Przełom Bugu/ } \\
\text { Wysoczyzna Drohiczyńska }\end{array}$ & FD30 & Nowacki \& Wasiluk 2004 \\
\hline 2007 & Dolina Rospudy & Równina Augustowska & FE27 & European Biodiversity Survey 2008 \\
\hline $1996-2008$ & Grzędy & Kotlina Biebrzańska & FE14 & Nowacki \& Frackiel 2010 \\
\hline 2008 & $\begin{array}{l}\text { Chelmowa Góra, } \\
\text { Dabrowa }\end{array}$ & Góry Świętokrzyskie & $\begin{array}{l}\text { EB03, } \\
\text { DB93 }\end{array}$ & Nowacki \& Nowacka 2012 \\
\hline
\end{tabular}




\section{Data from literature}

New and previously unpublished data collected by observers between 2005 and 2011 are ordered chronologically in the Table 1.

\section{Newly discovered sites}

1. Równina Augustowska: Molowiste [FE47], 25 VI 2005, 1 ex., leg. R. Slodzinka \& Ł. Matuszewski, coll. R. Slodzinka, a small elevation at the edge of a mesic coniferous forest and farm buildings, along the bank of Lake Serwy.

2. Pogórze Dynowskie: Zabratówka [EA83], 31 V 2010, 1 ex., leg. J. Bury, a clearing in a moist mixed forest.

3. Garb Tenczyński: Brzoskwinia [DA04], 07 VI 2010, 1 ex., male, leg. W. Zajda, a specimen collected in a dry locality in the immediate vicinity of a motorway.

4. Pogórze Dynowskie: Tarnawka [EA93], 09 VI 2010, 1 ex., phot. J. Bury, (Fig. 3.), a forest meadow in a mixed forest, a wet area periodically waterlogged because of obstruction of water flow by beavers' dams; there are a few artificial reservoirs nearby.

5. Pogórze Dynowskie: Jawornik Polski [EA92], 10 VI 2010, 1 ex., leg. J. Bury, a moist forest meadow in the valley of a small creek.

6. Kotlina Jasielsko-Krośnieńska: Krosno [EA50], 10 VI 2010, 1 ex., leg. W. Guzik, a built-up area on the outskirts of a town.

7. Pogórze Wiśnickie: Sobolów [DA52], 11 VI 2010, 1 ex., female, leg. W. Zajda, a wet meadow in the valley of a rivulet.

\section{Distribution in Poland}

In 1988-2010 X. graminea was recorded in Poland from 17 different $10 \times 10 \mathrm{~km}$ UTM squares [FA87, FB40, FB41, FE57, FB79, FC18, FC70, FC49, FC19, FC28, FD30, FE27, FE14, EB03, DB93] - literature data. Additionally, between 2005 and 2010, X. graminea was first reported from 7 UTM squares located in north-eastern, south-eastern and southern Poland: [DA04, DA52, EA50, EA83, EA92, EA93, FE47] - new data. Most of the new records described in the present paper come from southern and south-eastern Poland, where the species was first reported from Pogórze Dynowskie, Kotlina Jasielsko-Krośnieńska, Pogórze Wiśnickie and Garb Tenczyński in 2010.

Thus, X. graminea has been recorded in Poland at a total of 26 localities situated in 24 different UTM squares in the eastern and southern parts of the country. (Fig.3).

\section{DISCUSSION}

For almost 100 years, $X$. graminea was only known from a limited number of reports from Asia (Far East and East and Central Siberia). The first European records of this species were published in the 1980's and 1990's, indicating an on-going westward expansion.

In Poland, $X$. graminea was first recorded in 1988 at a few sites in Roztocze Środkowe and Roztocze Poludniowe (Nowacki 1989). Almost simultaneously, in 1992, it was encountered in Równina Augustowska in north-eastern Poland (Kokot 1995). By 2000, the species had been seen in a few other localities in the east of Poland: in Równina Łęczyńsko-Wlodawska, Wysoczyzna Siedlecka, within Podlaski Przelom Bugu and in Równina Bielska (Nowacki 1993, Łupiński 1996, Nowacki \& Holowiński 1999, Wąsala 2001, Łupiński \& Wasiluk 2002) (Fig. 3). Until 2007, X. graminea was only known from localities in eastern Poland, which might be taken to indicate a halting or slowing-down of the expansion. The previously known westernmost sites in Roztocze Środkowe and Wysoczyzna Siedlecka marked the western limit of the global range of the species, in some extreme cases for nearly 20 years. The few newly 
discovered sites in Równina Augustowska and Kotlina Biebrzańska (European Biodiversity Survey 2008, Nowacki \& Frackiel 2010) testified only to a minor westward expansion of $X$. graminea in north-eastern Poland. At the same time, there was a rise in the number of colonies in areas known to be within its range, the species being relatively frequently encountered at some of these localities (Nowacki \& Wasiluk 2004, European Biodiversity Survey 2008).

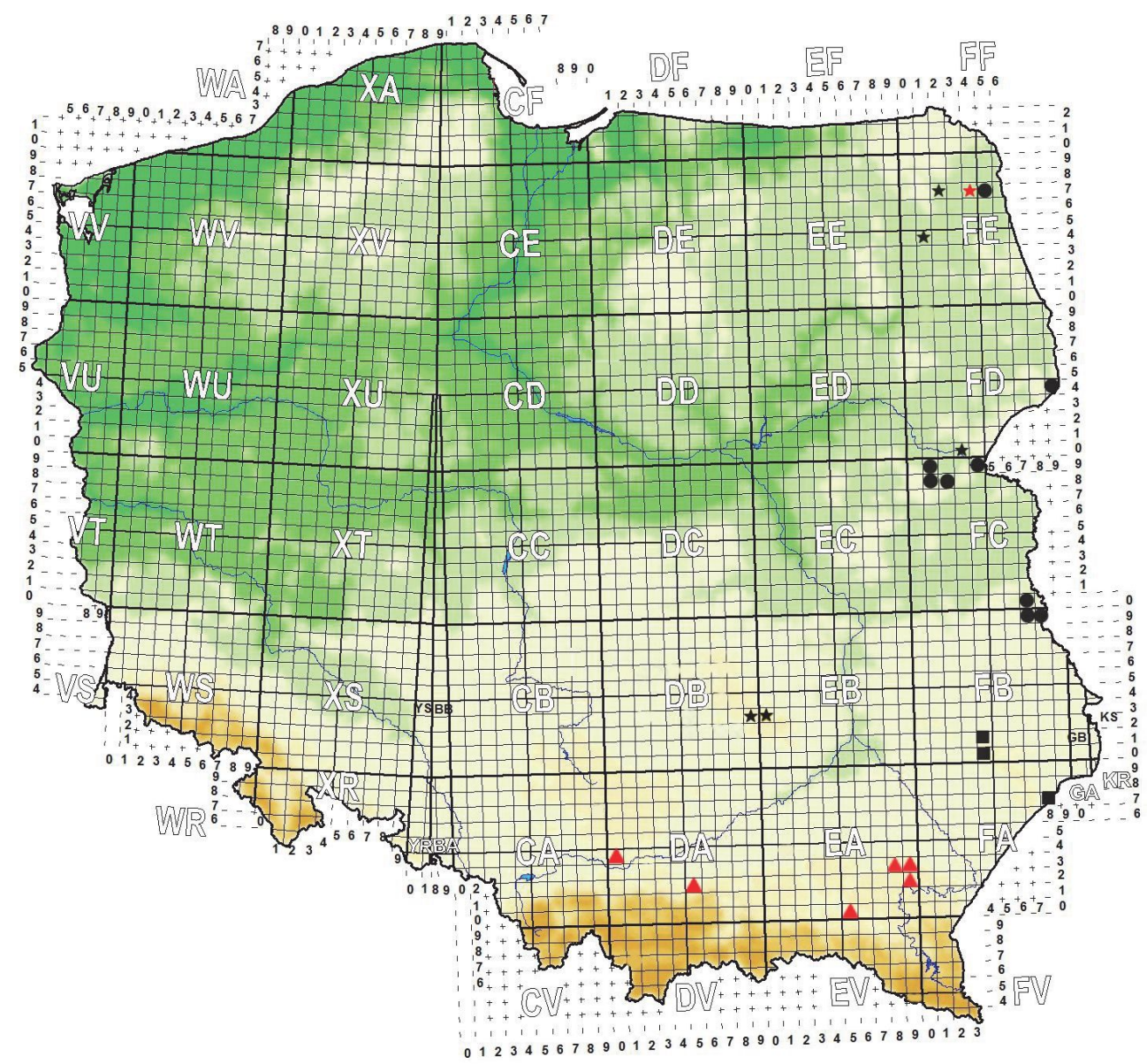

Fig. 3. Change of disrtibution of Xylomoia graminea in Poland. - localities discovered between 1988 and 1991 (Nowacki 1989, 1992), - localities discovered between 1992 and 2000 (Kokot 1995, Nowacki 1993, Lupiński 1996, Nowacki \& Holowiński 1999, Wąsala 2001, Lupiński \& Wasiluk 2002, Nowacki \& Wasiluk 2004), - localities discovered between 2001 and 2009 (Nowacki \& Wasiluk 2004, European Biodiversity Survey 2008, Nowacki \& Frąckiel 2010, Nowacki \& Nowacka 2012 and a new locality discovered in 2005). $\boldsymbol{\Delta}$ - new localities discovered in 2010. Black symbols - data from literature, red symbols - new data.

The situation changed radically in 2008, when species was found for the first time in Góry Świętokrzyskie, to the west beyond the Wisła River Valley (Nowacki \& Nowacka 2012). The next records were noted during observations in Malopolska and Podkarpacie in 2010, when $X$. graminea was found for the first time on Pogórze Dynowskie, Kotlina Jasielsko-Krośnieńska, Pogórze Wiśnickie and Garb Tenczyński, at a considerable distance from previously known sites in the east of Poland. 
The new data provided in this paper furnish definite proof of a continuing expansion of $X$. graminea westwards, although its causes and current pace are difficult to determine unequivocally. At this junction, it is legitimate to mark the western limit of the range of $X$. graminea approximately $250 \mathrm{~km}$ west of the current limit in the south-east. This is an important update on the distribution of $X$. graminea both in Poland and globally (Fig. 1 and 3 ).

The finding of $X$. graminea in south-eastern Poland indicates that it may be possible to find the species, in suitable habitat conditions, also outside its current range, and should encourage targeted searches for $X$. graminea also in other parts of Poland. Moreover, since most domestic localities of $X$. graminea are very close to the eastern state border, it is worthwhile to search for this moth in the neighbouring countries of Belarus, or even Latvia and Estonia, where it has not been reported to date. It would be advisable to conduct regular observations at the new localities of $X$. graminea in southern Poland to determine whether these sites are occupied permanently or the sightings were actually ephemeral. Detailed studies of the biology of the species, which is not sufficiently recognised, should also be initiated.

At the same time, it is worth pointing out that the occurrence of $X$. graminea is associated with the presence of suitable habitats, which are often found within protected areas, as is the case with all new localities in Pogórze Dynowskie, situated within the special habitat protection area "Nad Husowem", part of the Nature 2000 network. Protection is afforded there for well-preserved communities of fertile beech forest (Dentario glandulosae-Fagenion, Galio odorati-Fagenion), Central European and subcontinental linden-oak forest (Galio-Carpinetum, Tilio-Carpinetum) and non-forested areas with fragments of biologically valuable meadow ecosystems and a large complex of ponds (Olbrycht \& Bury 2011). The occurrence of $X$. graminea in this area confirms the necessity of preserving such habitats in intact form.

\section{ACKNOWLEDGEMENTS}

The authors wish to thank all those who have contributed to the writing of this article, and particularly the suppliers of the materials: Wojciech Guzik, Łukasz Matuszewski and Robert Slodzinka.

\section{REFERENCES}

AHOLA M. \& SILVONEN K. 2008. Larvae of Northern European Noctuidae. Vol. 2. Viestipaino Oy., Tampere. 672 pp. BuszKo J. 2004. Sówka puszczykówka, pp. 63-64. In: ADAMSKI P., BARTEL R., BERESZYSKI A., KAPEL A. \& WITKOWSKI Z. (eds), Gatunki Zwierząt (z wyjątkiem ptaków). Poradniki ochrony siedlisk i gatunków. 6. Natura 2000. Podręcznik metodyczny. Ministerstwo Środowiska. Warszawa.

BUSzKo J. 2010. Ksylomka striks (sówka puszczykówka) Xylomoia strix Mikkola, 1980. Pp. 85-89. In: MAKOMASKAJUCHIEWICZ M. (ed.), Monitoring gatunków zwierząt. Przewodnik metodyczny. I, GIOŚ [Glówny Inspektorat Ochrony Środowiska], Warszawa.

BUszKo J. \& NowACKI J. 2000. The Lepidoptera of Poland, A Distributional Checklist. Polish Entomological Monographs, Poznań - Toruń, 1: 96.

EUROPEAN BIODIVERSITy SURVEY 2008. Biodiversity Survey Rospuda Valley, Final Report. Groningen, European Biodiversity Survey; http://www.biodiversitysurvey.eu [31.08.2011]

GRAESER L. 1889. Beitrage zur Kenntniss der Lepidopteren-Fauna des Amurlandes. Berliner Entomologische Zeitung 33: $309-414$

HERZ O. 1904. Lepidoptera von Korea. Noctuidae \& Geometridae. Annuaire du Muse'e Zoologique de l'Academie Impe' riale des Sciences de St.Petersbourg, 9: 263-390.

KARSHOLT O. \& VAN NIEUKERKEN E. J. 2011. Fauna Europaea: Lepidoptera, Noctuidae. Fauna Europaea, version 2.4., www.faunaeur.org [31.08.2011]

KLYUCHKO Z. F. 1995. Xylomoia graminea (Lepidoptera, Noctuidae) - a species new for Ukrainian fauna. Journal of the Ukrainian Entomological Society $1(3-4): 38$.

KLyUChKo Z. F., PLyUSHCH I. \& SHESHURAK P. N. 2001. Annotirowannyj katalog sowok (Lepidoptera, Noctuidae) fauny Ukrainy. Instytut Zoologii NAN Ukrainy, Kijów. 884 pp. [In Ukrainian]

KоKот A. 1995. Nowe dla Puszczy Augustowskiej gatunki sówkowatych (Lepidoptera, Noctuidae). Wiadomości Entomologiczne 14: 62 .

KONDRACKI J. 2002. Geografia regionalna Polski. Państwowe Wydawnictwo Naukowe, Warszawa. 444 pp. 
LAFontAINE J. D. \& SCHMIDT B. C. 2010. Annotated checklist of the Noctuoidea (Insecta, Lepidoptera) of North America north of Mexico. ZooKeys 40: 1-239. doi: 10.3897/zookeys.40.414

LUPIŃSKI D. 1996. Co slychać w świecie motyli. [What is new in the world of butterflies.] Biuletyn MTOF, 2: 26 27. [In Polish]

LUPIŃSKI D. \& WASLUK D. 2002. Motyle nocne Macroheterocera Podlaskiego Przelomu Bugu. [In:] DOMBROWSKI A,

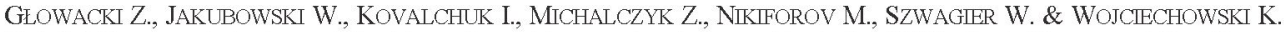
H. (eds.) Korytarz ekologiczny doliny Bugu. Stan - Zagrożenia - Ochrona. Fundacja IUCN Poland, Warszawa. 151-154.

MIKKOLA K. 1980. Two new noctuid species from Northern Europe: Polia sabmeana n. sp. and Xylomoia strix n. sp. (Lepidoptera, Noctuidae: Hadeninae and Amphipyrinae). Notulae Entomologicae 60: 217-222.

MIKKOLA K. 1998. Revision of the genus Xylomoia Staudinger (Lepidoptera: Noctuidae), with descriptions of two new species. Systematic Entomology 23: 173-186.

NOWACKI J. 1989. Xylomoia graminea (Graeser, 1888) nowy dla fauny Polski i Europy przedstawiciel sówkowatych (Lepidoptera, Noctuidae). Przegląd Zoologiczny 33: 445-447.

NowACKI J. 1992. Sówkowate (Lepidoptera, Noctuidae) Roztocza. Fragmenta Faunistica 35: 397-414.

NOWACKI J. 1993. Nowe stanowiska sówkowatych (Lepidoptera, Noctuidae) w Polsce. Wiadomości Entomologiczne 12: 62.

NOWACKI J. 1998. The Noctuids (Lepidoptera, Noctuidae) of central Europe. Bratislava, 143 pp.

NOWACKI J. \& FRACKIEL K. 2010. The influence of anthropogenic factors on the biodiversity of noctuid moths (Lepidoptera, Noctuidae) in marsh habitats of the Biebrza valley. Polish Journal of Entomology 79: 307-318.

NowACKI J. \& HolowIŃsKi M. 1999. Sówkowate (Lepidoptera, Noctuidae) Lasów Sobiborskich. Wiadomości Entomologiczne 18 (Suppl. 1): 1-60.

NOWACKI J. \& NOWACKA J. 2012. Materialy do poznania sówkowatych (Lepidoptera: Noctuidae) Gór Świętokrzyskich. Wiadomości Entomologiczne 31 (1): 35-40.

NOWACKI J. \& WASILtK, D. 2004. Sówkowate (Lepidoptera, Noctuidae) poludniowego Podlasia. Wiadomości Entomologiczne 23, Suppl:: 1-48.

Poltavsky A. N. \& ARTOHIN K. S. 2000. New and rare Macrolepidoptera of the Rostov-on-Don region in South Russia (Lepidoptera). Phegea 28 (4): 131-147.

Sugi S. 1982. Noctuidae. Pp. 669-913. In: InAuE H., Sugi S., Kuroko H., Moriuti S., KawaBE A. (eds), Moths of Japan. I. Text. Kadansha, Tokyo.

SVIRIDOV A. V. 1985. Material for knowledge of the fauna of Noctuidae (Lepidoptera) of the northern Amur Area. Sbornik Trudy Zoologicheskogo Muzeya MGU, 23: 155-182 [In Russian]

ŠVITRA G., BAČIANSKAS V., ÚsaITIS T., LuKOŠEVIČIUS D. 2011. Four new and 153 rare for the Lithuanian fauna Lepidoptera species recorded in 2011. New and Rare for Lithuania Insect species 23: 67-93.

OLBRYCHT T. \& BURY J. 2011. Specjalny obszar ochrony siedlisk Nad Husowem (PLH180025) In: RoGAEA D., MARCELA A. (eds), Obszary NATURA 2000 na Podkarpaciu. RDOŚ [Regionalna Dyrekcja Ochrony Środowiska] Rzeszów, 236-239.

WÁSALA R. 2001. Xylomoia graminea (Graeser) (Lepidoptera: Noctuidae) gatunek nowy dla fauny Puszczy Bialowieskiej. Wiadomości Entomologiczne 20: 280

ZLli A., RonkAy L. \& FBBiger M. 2005. Noctuidae Europaeae. Vol. 8, Apameini. Entomological Press, Sorø, 323 pp.

\section{STRESZCZENIE}

\section{[Rozmieszczenie Xylomoia graminea (Graeser, 1889) (Lepidoptera: Noctuidae) w Polsce]}

W pracy zebrano dostępne $\mathrm{w}$ literaturze oraz niepublikowane informacje dotyczace stwierdzeń $X$. graminea na terenie Polski. Do roku 2007 na podstawie obserwacji z 15 kwadratów UTM uważano, że $X$. graminea zasiedla wyspowo wschodnią część Polski, gdzie osiagga zachodnia granicę swego globalnego areału występowania. W roku 2008 gatunek zostal stwierdzony po raz pierwszy na dwóch stanowiskach w Górach Świętokrzyskich, na zachód od doliny Wisly. W latach 2005-2010 dodatkowo stwierdzono 7 nowych stanowisk tego gatunku w Polsce. Większość nowych stanowisk zlokalizowanych jest $\mathrm{w}$ poludniowo-wschodniej i południowej części kraju, gdzie w 2010 roku gatunek ten zostal po raz pierwszy wykazany z Pogórza Dynowskiego, Kotliny Jasielsko-Krośnieńskiej, Pogórza Wiśnickiego oraz Garbu Tenczyńskiego. Stwierdzenie nowych stanowisk $X$. graminea w znacznej odległości od znanych dotychczas lokalizacji świadczy o zachodzacej obecnie ekspansji tego gatunku w kierunku południowym i zachodnim, i skłania do podjęcia dalszych badań, w celu monitorowania zmian rozmieszczenia tego motyla na terenie naszego kraju. 